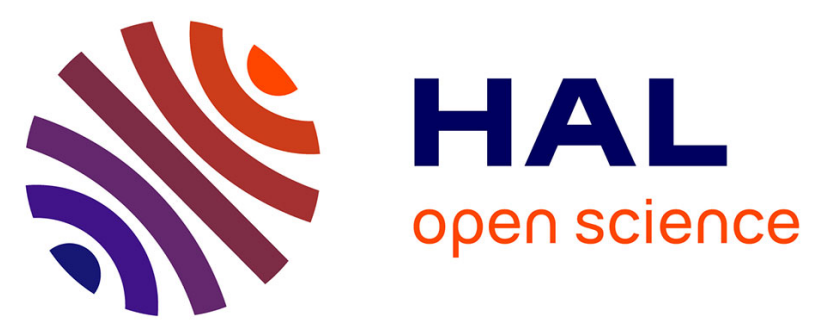

\title{
Assessing subsidence rates and paleo water-depths for Tahiti reefs using U-Th chronology of altered corals
} Alexander L. Thomas, Kazuhiko Fujita, Yasufumi Iryu, Edouard Bard, Guy Cabioch, Gilbert Camoin, Julia E. Cole, Pierre Deschamps, Nicolas Durand, Bruno Hamelin, et al.

\section{To cite this version:}

Alexander L. Thomas, Kazuhiko Fujita, Yasufumi Iryu, Edouard Bard, Guy Cabioch, et al.. Assessing subsidence rates and paleo water-depths for Tahiti reefs using U-Th chronology of altered corals. Marine Geology, 2012, 295-298, pp.86 - 94. 10.1016/j.margeo.2011.12.006 . hal-01495168

\section{HAL Id: hal-01495168 \\ https://hal.science/hal-01495168}

Submitted on 12 Apr 2021

HAL is a multi-disciplinary open access archive for the deposit and dissemination of scientific research documents, whether they are published or not. The documents may come from teaching and research institutions in France or abroad, or from public or private research centers.
L'archive ouverte pluridisciplinaire HAL, est destinée au dépôt et à la diffusion de documents scientifiques de niveau recherche, publiés ou non, émanant des établissements d'enseignement et de recherche français ou étrangers, des laboratoires publics ou privés. 


\section{Assessing subsidence rates and paleo water-depths for Tahiti reefs using U-Th chronology of altered corals}

Alexander L. Thomas, ${ }^{\text {a, }}$

Kazuhiko Fujita ${ }^{\mathrm{b}}$,

Yasufumi Iryu ${ }^{\mathrm{c}, 1}$,

Edouard Bard ${ }^{\mathrm{d}}$, Guy Cabioch $^{\mathrm{e}, \dagger}$, Gilbert Camoin ${ }^{\mathrm{d}}$, Julia E. Cole ${ }^{\mathrm{f}}$, Pierre Deschamps ${ }^{\mathrm{d}}$, Nicolas Durand ${ }^{\mathrm{d}}$, Bruno Hamelin $^{\mathrm{d}}$, Katrin Heindel ${ }^{\mathrm{g}, 2}$, Gideon M. Henderson ${ }^{\mathrm{a}}$, Andrew J. Mason ${ }^{\mathrm{a}}$, Hiroki Matsuda $^{\mathrm{h}}$, Lucie Ménabréaz ${ }^{\mathrm{d}}$, Akitoshi Omori ${ }^{\mathrm{i}}$, Terry Quinn ${ }^{\mathrm{j}, 3}$, Saburo Sakai ${ }^{\mathrm{k}}$, Tokiyuki Sato, $\quad$ Kaoru Sugihara $^{\mathrm{m}}$, $\quad$ Yasunari Takahashic $^{\mathrm{c}}$, Nicolas Thouveny ${ }^{\mathrm{d}}$, Alexander W. Tudhope ${ }^{\mathrm{n}}$, Jody Webster ${ }^{\mathrm{o}, 4}$, Hildegard Westphal ${ }^{\mathrm{g}, 5}$, Yusuke Yokoyama ${ }^{\mathrm{k}, \mathrm{p}, \mathrm{q}}$,

* Corresponding Author: E-mail, alext@earth.ox.ac.uk; Tel, +44 (0)1865 272047; Fax +44 (0)1865 272072 contributions Guy made, not only to the IODP expedition to Tahiti, but also more widely as a carbonate geologist. His presence in the coral reef community will be missed. 


\section{Abstract}

We present uranium-thorium chronology for a $102 \mathrm{~m}$ core through a Pleistocene reef at Tahiti 49 (French Polynesia) sampled during IODP Expedition 310 "Tahiti Sea Level”. We employ total and 50 partial dissolution procedures on the older coral samples to investigate the diagenetic overprint of 51 the uranium-thorium system. Although alteration of the U-Th system cannot be robustly corrected, 52 diagenetic trends in the U-Th data, combined with sea level and subsidence constraints for the 53 growth of the corals enables the age of critical samples to be constrained to marine isotope stage 9.

54 We use the ages of the corals, together with $\delta^{18} \mathrm{O}$ based sea-level histories, to provide maximum 55 constraints on possible paleo water-depths. These depth constraints are then compared to independent depth estimates based on algal and foraminiferal assemblages, microbioerosion patterns, and sedimentary facies, confirming the accuracy of these paleo water-depth estimates. We also use the fact that corals could not have grown above sea level to place a maximum constraint on the subsidence rate of Tahiti to be $0.39 \mathrm{mka}^{-1}$, with the most likely rate being close to the existing 60 minimum estimate of $0.25 \mathrm{mka}^{-1}$.

63 Keywords: paleo water-depth; Tahiti, IODP Expedition 310; island subsidence; coral; U-Th; open system. 


\section{Introduction}

66

\subsection{Paleo water-depth reconstructions}

68

69 Estimation of the overlying depth of water is crucial for the reconstruction of past sea levels from geological deposits (typically coral reefs or marine sediments). Ideally a narrow range of possible

paleo water-depth, coupled with accurate uplift/subsidence correction, can be combined with a chronological constraint to produce an accurate and precise sea level history. This approach has succeeded in producing archives of sea level from a variety of localities (Bard et al., 1996; Chappell and Polach, 1991; Peltier and Fairbanks, 2006). These records have benefited from relatively shallow paleo water-depths reducing the potential for uncertainty in the correction from waterdepth estimate. Where water-depth was thought to be larger, however, accurately recording changes in sea level is more problematic. Also, producing a calibration of fossil assemblage to paleo waterdepth involves the study of modern environments of deposition (Hopley, 1986, Montaggioni and Faure, 1995, Cabioch et al., 1999, Humblet et al., 2009, Hongo and Kayanne, 2010) or the examination of fossil material from locations, and times, for which past sea level is well constrained (Montaggioni, 2005). In addition, changes in water transparency, e.g. as an effect of changed trophic conditions, introduce a telescoping effect on biotic assemblages, in particular corals, used for the reconstruction of past sea levels (Heindel et al., 2009a, b). Changes of the water-depths at which assemblages are related through time will therefore also cause sea level estimates to be in error if the calibration is not appropriate.

Often estimates of paleo water-depth are made from material for which some age control already exists (eg Thomas et al., 2009), therefore some bias may be introduced from the expectation of how 
sea level changed during the time that the material represents. Two recent papers (Fujita et al., 2010; Iryu et al., 2010) have made independent estimates of paleo water-depth (bathymetric ranges) from the same drill core through a carbonate reef, sampled during Integrated Ocean Drilling Program (IODP) Expedition 310 "Tahiti Sea Level". These two sets of estimates are based on benthic foraminifera (Fujita et al., 2010) and non-geniculate coralline algal assemblages (Iryu et al., 2010), and were made without radiometric age control. The addition of age control provided by UTh measurements of fossil corals from Hole IODP-310-M0005D, coupled with comparison to "known" sea level history, provided the opportunity to check both the robustness of these paleo water-depth estimates as well as their validity back in time. In addition paleo water-depth estimates may be assessed, from post-LGM (Last Glacial Maximum) material, were good chronological and sea level information was available, in an example where water depth was inferred from the basis of the photic levels recorded by microbioerosion patterns (Heindel et al. 2009a, b).

\subsection{Subsidence rate}

Volcanic islands emplaced onto oceanic lithosphere are typically found to be subsiding owing principally to the effect of mass loading of the island depressing the underlying oceanic lithosphere (Watts and Zhong, 2000), along with a small component of subsidence related to the cooling and thickening of the oceanic lithosphere itself. At Tahiti - on 74 Ma crust (Muller et al., 2008) - this secondary component equates to only $0.0088 \mathrm{mka}^{-1}$ (Stein and Stein, 1992), the bulk of the subsidence resulting from the loading of the island during the main shield building phase of volcanism 1.4 - 0.87 Ma (Hildenbrand et al. 2004). Constraining this rate of subsidence is not only important for our understanding of crust-mantle dynamics (Moore, 1970; Courtney and White, 112 1986; Zhong and Watts, 2002) but is also crucial for the accurate reconstruction of past sea levels 
113 from relative sea level indicators on such ocean islands (Bard et al., 1996; Muhs et al., 2002; Szabo et

114 al., 1994). Modern geodetic measurements (Fadil et al., 2010) of vertical island movement suffer

115 from relatively short baselines and also form the potential of anthropogenically driven ground

116 movement (Bird, 1993) biasing results. Geodetic measurements of subsidence at Tahiti typically

117 have uncertainties that are of comparable size to the rate measured $\left(0.3 \pm 0.4 \mathrm{mka}^{-1}\right.$ (Fadil et al.,

118 2010)). It is therefore advantageous to estimate subsidence over longer time periods, giving a time-

119 averaged subsidence rate.

120

121 Previous estimates of long-term subsidence at Tahiti have provided minimum estimates based on

122 radiometric dating of, now submerged, sub-aerial lava flows of 0.21 and $0.25 \mathrm{mka}^{-1}$ (LeRoy, 1994;

123 Bard et al., 1996). Short-term subsidence rate has been estimated from the position of Holocene 124 shoreline deposits and is significantly lower at $0.15 \mathrm{mka}^{-1}$ (Pirazzoli et al., 1985), although other 125 higher Holocene estimates of $0.3-0.4 \mathrm{mka}^{-1}$ (Montaggioni, 1988) have also been made. Large 126 uncertainties of these Holocene estimates arise from the relatively short baselines of the measurements, amplifying uncertainties in paleo-sea level and water-depth used in subsidence rate calculations. Here we use the additional constraints provided by U-Th dating of much older fossil corals to provide a maximum estimate of subsidence rate to better constrain the history of the island.

\subsection{Core description}

133 More than $630 \mathrm{~m}$ of cores were recovered during IODP Expedition 310 (Expedition 310 Scientists,

134 2007), and were described sedimentologically within the standardized procedure of the IODP 135 onshore Science Party (Camoin et al., 2007). The deglacial coral reef framework is heavily encrusted 136 by microbialites, in many cases preceded by coralline algal crusts (Seard et al., 2011; Westphal et al., 
137 2010). Most of the reef framework is therefore preserved in growth position. Hole IODP-310-

138 M0005D was drilled at $17^{\circ} 45.9915^{\prime} \mathrm{S} 149^{\circ} 33.0476^{\prime} \mathrm{W}$ in $59.63 \mathrm{~m}$ water-depth on the south-western

139 side of Tahiti, and reached down to $161.8 \mathrm{mbsl}$ (meters below modern sea level, defined as lowest

140 astronomical tide). A total of 36 core sections were recovered from this hole (Fig. 1). Although the

141 conventional core recovery was $64.86 \%$ (Camoin et al. 2007), accounting for void space, 97.35\% of

142 the available material was retrieved (Inwood et al., 2008).

144 The lithology of Hole IODP-310-M0005D is described in detail by Camoin et al. (2007) and the pre 145 last glacial sections are summarised by Fujita et al. (2010) and Iryu et al. (2010). Briefly the hole 146 consists of: The postglacial sequence of coralgal framestone and microbialite of cores 1R-6R, from 14791.39 - 82.63 mbsl, which was deposited while sea level rose during the last deglaciation (the 148 chronology will be presented elsewhere Deschamps et al., In Revision, Camoin et al., In Revision). 149 An older sequence of coralgal framestone in cores 7R-8R; a rhodolith floatstone and grainstone in 150 cores 9R-15R; a sandy Halimeda floatstone, and packstone in cores 16R-20R; a further sequence of coralgal framestone in cores $20 \mathrm{R}$ and $21 \mathrm{R}$; a microbialite sequence in cores $21 \mathrm{R}-22 \mathrm{R}$; a sequence of sandy grainstones with massive Porites corals in cores 23R-28R; a thin sequence of coralgal

153 framestone in core 29R; a rhodolith coral floatstone in core 29R; a thick sequence of coralgal and coral framestones and coral floatstones in cores 30R-35R; a coral floatstone sequence in cores 35R36R; and the base of the hole is marked by a sandy bioclastic grainstone at the base of core 36R (Fig. 1a). Iryu et al. (2010) identify three distinct horizons within Hole IODP-310-M0005D which represent erosional hiatuses, based on the presence of sharp contacts with evidence of carbonate dissolution in the underlying unit. These unconformities are in cores 21R, 29R, and 36R (Fig. 1a). 


\section{Analytical techniques}

161 Coral samples were identified as being pristine by visual, and thin section, inspection and by X-ray

162 diffraction to ensure that they were primary aragonite ( $0.26 \%$ calcite detection limit). Approximately

$1630.3 \mathrm{~g}$ sub-samples of coral were cut using a hand-held diamond wheel. These chips were then

164 cleaned by ultra-sonication in $18 \mathrm{M} \Omega \mathrm{cm}$ (Milli-Q) water. For $\mathrm{U}$ and Th analysis, samples were

165 weighed into Teflon beakers and spiked with a mixed ${ }^{229} \mathrm{Th}^{.236} \mathrm{U}$ spike ((Robinson et al., 2004a), with

$166 \quad 0.006 \%{ }^{230} \mathrm{Th}, 0.02 \%{ }^{238} \mathrm{U}, 0.004 \%{ }^{235} \mathrm{U}$, and $39 \mathrm{ppt}{ }^{234} \mathrm{U}$ impurities, and calibrated with the HU-1

167 standard assuming the half lives and U:Th of Cheng et al. 2000). Total dissolution is achieved by

168 drop-wise addition of 7.5 $\mathrm{NNO}_{3}$ to the sample immersed in Milli-Q water. Once dissolved, any

169 remaining organic material is removed by refluxing in hot $15 \mathrm{~N} \mathrm{HNO}_{3}$ followed by an attack in cold

170 aqua regia. The sample is converted to nitrate form by repeated drying and dissolution in

$17115 \mathrm{~N} \mathrm{HNO}_{3}$ before being prepared for anion exchange chromatography to separate $\mathrm{U}$ and Th from

172 the sample matrix and each other. The chromatographic separation followed the procedure of

173 Thomas et al., (2006) with volumes scaled to accommodate $2 \mathrm{ml}$ of resin.

175 To investigate the possibility that deviation from closed system of $\mathrm{U}$ and $\mathrm{Th}$ is localised to the surfaces of the coral, a leaching approach was taken. To ensure only the surfaces of the corals were leached, a weak acid attack with ascorbic acid $(63 \mu \mathrm{M})$ was used, incorporating NaEDTA (25 $\mu \mathrm{M})$ to ensure leached Th was not reabsorbed to the remaining solids, following the procedure of

179 Lomitschka and Mangini (1999), and varying the leaching time from 0.5 to 3 hours. Because the coral used for this partial leaching procedure was of the finely porous genus Porites, it was crushed and passed through a $106 \mu \mathrm{m}$ sieve (the scale of the theca is approximately $100 \mu \mathrm{m}$ ) so that all of the surfaces of the coral were equally subject to the acid leach. Chips of uncrushed coral were also 
samples were rinsed with Milli-Q water to remove any remaining leachate and NaEDTA, they were then prepared for U-Th analysis in the same way as for unleached samples. Measurement of U and

Th from the leachate was not possible due to the difficulty in separating the leached Th and U from the EDTA complexing agent.

Measurement of $\mathrm{U}$ and Th isotopes was by Nu instruments MC-ICP-MS in static mode. $\mathrm{U}$ and Th

isotopes were measured separately, with ${ }^{234} \mathrm{U}$ and ${ }^{230} \mathrm{Th}$ in an ion counter and all other isotopes in

191 Faraday collectors. Machine biases were corrected for using CRM-145 (for uranium), and an in-

192 house ${ }^{229} \mathrm{Th}:{ }^{230} \mathrm{Th}:{ }^{232} \mathrm{Th}$ standard (for thorium) (Mason and Henderson 2010), bracketing each

193 sample with 3 standard measurements to also asses instrumental reproducibility. For both U and Th

194 measurements the ${ }^{234} \mathrm{U}$ or ${ }^{230} \mathrm{Th}$ concentration is matched to the standard's so that the intensity of

195 the beam in the ion counter is equal, to negate any possible instrumental biases arising from non-

196 linear collector responses.

\section{Results}

Uranium and thorium concentrations and isotope ratios are presented in Table 1, and calculated ages in Table 2. Details of the biological assemblages and inferred paleo-environments are presented in Fujita et al. (2010) (benthic foraminifera) and Iryu et al. (2010) (coralline algae). The results of these two studies are summarized in Fig. 1. The foraminiferal assemblages were analysed from core sections M0005D-26R to $16 \mathrm{R}$ and have been interpreted as a shallow water environment $(15 \pm 15 \mathrm{mbsl})$ in sections $26 \mathrm{R}$ to $23 \mathrm{R}$ followed by a deepening upwards sequence in core sections 18R to $16 \mathrm{R}$ (from $45 \pm 15$ to $75 \pm 15 \mathrm{mbsl}$ ) (Fig. 1d). Coralline algal assemblages from all of the pre- 
interpreted are shallow from section M0005D-36R to 30R, deep in section 29R, shallow in sections $28 \mathrm{R}$ to $23 \mathrm{R}$, deep in $22 \mathrm{R}$ and $21 \mathrm{R}$, followed by a deepening upwards sequence from $21 \mathrm{R}$ to $17 \mathrm{R}$, and then deep water from 17R to 7R (Fig. 1g).

\section{Discussion}

\subsection{Partial dissolution of coral to "remove" open system U-Th contamination}

A hypothetical coral sample that incorporated uranium from seawater with a $\left({ }^{234} \mathrm{U} /{ }^{238} \mathrm{U}\right)$ of $1.146 \pm 0.005$ should follow the closed system evolution path (Fig. 2) as it ages: $\left({ }^{230} \mathrm{Th} /{ }^{238} \mathrm{U}\right)$ increasing as ${ }^{230} \mathrm{Th}$ is produced from decay of ${ }^{234} \mathrm{U}$, and $\left({ }^{234} \mathrm{U} /{ }^{238} \mathrm{U}\right)$ decreasing as initial excess ${ }^{234} \mathrm{U}$ incorporated from sea water, decays towards secular equilibrium $\left(\left({ }^{234} \mathrm{U} /{ }^{238} \mathrm{U}\right)=1\right)$. A range of potential seawater $\left({ }^{234} \mathrm{U} /{ }^{238} \mathrm{U}\right)$ is considered due to the potential for subtle secular variation in the isotopic composition of uranium in seawater (Esat and Yokoyama 2006). Deviation from this path is observed for many fossil corals (e.g. compilation in Henderson (2002) because of open-system behaviour over the history of the fossil. This open system behaviour is the result of gain or loss of any of the isotopes in the ${ }^{238} \mathrm{U}_{-}^{230} \mathrm{Th}$ decay chain $\left({ }^{238} \mathrm{U},{ }^{234} \mathrm{Th},{ }^{234} \mathrm{~Pa},{ }^{234} \mathrm{U}\right.$, or $\left.{ }^{230} \mathrm{Th}\right)$. Often the gain/loss of ${ }^{234} \mathrm{U}$ and ${ }^{230} \mathrm{Th}$ during open system behaviour is coupled leading to linear arrays of data in $\left({ }^{234} \mathrm{U} /{ }^{238} \mathrm{U}\right)-\left({ }^{230} \mathrm{Th} /{ }^{238} \mathrm{U}\right)$ space, for corals which are thought to be of similar age (Gallup et al., 1994). This coupled behaviour has been used to apply corrections to coral U-Th data, which fall away from the hypothetical closed-system evolution path, to calculate open-system ages (Scholz et al., 2004; Thompson et al., 2003; Villemant and Feuillet, 2003). These approaches of correcting for open-system behaviour rely on the data falling on a linear array and the assumption that a single 
core 24R (Table 1 and Fig. 2) indicate these criteria are not upheld (the measurements show

233 enhanced elevation of ${ }^{230} \mathrm{Th} /{ }^{238} \mathrm{U}$ without the associated elevated ${ }^{234} \mathrm{U} /{ }^{238} \mathrm{U}$ typical of coupled

234 addition), and therefore open system correction to these data will not necessarily yield more 235 accurate ages.

237 The partial dissolution of coral 23R illustrates that successive removal of surface material generally 238 moves the position of the coral towards the closed system age evolution line in $\left.239\left({ }^{234} \mathrm{U} /{ }^{238} \mathrm{U}\right)-{ }^{230} \mathrm{Th} /{ }^{238} \mathrm{U}\right)$ space (Fig. 4). This indicates that the sequential dissolution technique may 240 be useful in isolating portions of corals that have not been subject to open system behaviour, by 241 preferential removing the outer surfaces which have been potentially exposed to open system 242 behaviour through interaction of uranium and/or thorium isotopes between the coral and pore 243 fluid. However, the measured values of $\left({ }^{234} \mathrm{U} /{ }^{238} \mathrm{U}\right)$ and $\left({ }^{230} \mathrm{Th} /{ }^{238} \mathrm{U}\right)$ for partially dissolved sub 244 samples should not be considered more representative of a closed system, because removal of the 245 outer surface of the coral by partial dissolution is on such a small scale that there will have been 246 recoil exchange between the high ${ }^{234} \mathrm{U}$ and ${ }^{230} \mathrm{Th}$ exterior and the "unaltered" interior (Henderson et 247 al., 2001). The $\left({ }^{234} \mathrm{U} /{ }^{238} \mathrm{U}\right)$ and $\left({ }^{230} \mathrm{Th} /{ }^{238} \mathrm{U}\right)$ of the leached samples should not therefore be used to 248 calculate a conventional closed system age. Indeed, some of the leached sub-samples move away 249 from the closed system line, which may represent a more complex heterogeneous alteration of the 250 coral or an artefact of the leaching procedure. That the leached coral U-series data lie close to the 251 closed system evolution path, coupled with constraints based on our knowledge of the subsidence 252 rate of Tahiti and the history of global sea level, an approximation of the age of the coral can be 253 made. 
257 A previous estimate of the subsidence rate of Tahiti has been made from a K-Ar age, of $258549 \pm 11 \mathrm{ka}$, on a now submerged lava flow, at $114 \mathrm{mbsl}$ (Bard et al., 1996). This placed a minimum 259 constraint on the subsidence rate of $0.207 \pm 0.004 \mathrm{mka}^{-1}$. A faster rate being possible if the lava 260 flow was emplaced substantially above sea level, and lower rate if the lava was emplaced during a 261 period of sea level lowstand. This is in reasonable agreement with an earlier unpublished estimate of $2620.25 \mathrm{mka}^{-1}$ (LeRoy, 1994), using similar methodology. A lower, Holocene, subsidence rate of $2630.15 \mathrm{mka}^{-1}$ has been inferred from the elevation of corals and beach deposits on Tahiti relative to nearby 'stable' islands (Pirazzoli et al., 1985). This discrepancy between the longer and shorter timescale estimates is not unexpected. The subsidence rate due to the loading of an island on the oceanic lithosphere is time dependent, being most rapid at the time of loading and reducing with time (Watts and Zhong, 2000). In consideration of the longer timeframe, a minimum subsidence rate of $0.25 \mathrm{mka}^{-1}$ is assumed here, based on the expectation that subsidence rate in the Holocene is a minimum constraint on the rates further into the past. Also, that the ages of corals interpreted here are 100s of ka old, similar to the age from which this subsidence rate has been measured, makes this a suitable subsidence assumption.

Constraining the time that corals in M0005D could have grown is possible by considering that the corals could only have grown while sea level was above the position they were in - assuming the corals are found in growth position. Reconstructing the elevation of core M0005D back through time (using a subsidence rate of $0.25 \mathrm{mka}^{-1}$ ), comparison with a continuous estimate of sea level (Bintanja and van de Wal, 2008), and the U-Th constraint that M0005D-20R was deposited during the MIS 6-5 transition (Table 2 and Fig. 3), indicates that the only times that core section 
M0005D-23R would have been underwater, are: MIS 6.5; MIS 7; MIS 8.5; MIS 9 and MIS 11 (Fig. 3a).

The U-series data for the partial leaching of sample $23 \mathrm{R}$ and the multiple measurements of corals from 24R suggests that both corals grew during MIS 9 (Fig. 2). Assuming - as seams reasonable that seawater $\left({ }^{234} \mathrm{U} /{ }^{238} \mathrm{U}\right)$ remained close to 1.146 (Henderson 2002; Robinson et al., 2004b), these corals appear to have undergone open system behaviour in which there was a significant amount of

${ }^{230} \mathrm{Th}$ addition as well as the possibility of coupled ${ }^{234} \mathrm{U}_{-}^{230} \mathrm{Th}$ addition. It is possible that seawater 287 may have been higher during MIS 9, Andersen et al. 2010 suggest it may have been as high as 1.152. If this higher seawater $\left({ }^{234} \mathrm{U} /{ }^{238} \mathrm{U}\right)$ is considered then it suggests this coral has undergone less open-system alteration and hence more confidence that this coral is of MIS 9 age.

An upper limit on the subsidence rate can be determined from this new age estimate: that these corals are of MIS 9 age. If the magnitude of the highstand during MIS 9 is inferred from $\delta^{18} \mathrm{O}$ based reconstructions of sea level as $0 \mathrm{mbsl}$ at $325 \mathrm{ka}$ (Bintanja and van de Wal, 2008) or $6 \mathrm{mbsl}$ at $329 \mathrm{ka}$ (Rohling et al., 2009), and the corals are assumed to have grown at sea level, then the subsidence rate would be $0.39 \mathrm{mka}^{-1}$ or $0.36 \mathrm{mka}^{-1}$ respectively. Uncertainty of the magnitude of the highstand of $\pm 10 \mathrm{~m}$ or in the timing of the highstand of $\pm 10 \mathrm{ka}$ leads to uncertainty the subsidence rate of 0.03 and $0.01 \mathrm{mka}^{-1}$, respectively. This is a maximum constraint of the subsidence rate because the corals may not have grown during the absolute maximal sea level highstand, instead growing while sea level was slightly lower as it rose (fell) to(from) the highstand and/or could, as is likely, have grown in a depth of water greater than zero. A paleo water-depth of $15 \mathrm{~m}$, as has been suggested for these corals (Fujita et al., 2010), would reduce the maximum subsidence rate by $0.045 \mathrm{mka}^{-1}$. These 
$0.39 \pm 0.03 \mathrm{mka}^{-1}$, although it is likely to have been lower, allowing for the depth of water that the corals grew under, and for the possibility that they did not grow at the sea level maximum.

\subsection{Comparison of paleo water-depth estimates with sea level history and age constraints}

The age constraints provided by U-Th dating can be used to assess water-depth estimates made from fossil assemblages (Fujita et al., 2010; Iryu et al., 2010). A coral from M0005D-20R-2W has yielded a robust U-Th age (Thomas et al 2009). This coral was broken into two fragments in the core. While the upper fragment (5D8146, Tables 1 and 2) has $>1 \%$ calcite and the replicate U-Th ages do not agree, the lower fragment (5D8006, Tables 1 and 2) appears to be purely aragonite with replicate ages in agreement at $133.6 \pm 1.0$ and $133.7 \pm 0.4 \mathrm{ka}$. Although the $\left({ }^{234} \mathrm{U} /{ }^{238} \mathrm{U}\right)_{\mathrm{i}}$ of this fragment indicates that there has been some open-system behaviour it is reasonable to assume that this coral grew at some time approximately 133-134 ka. The age of this coral, when compared to other sea level records for this interval (Andrews et al., 2007; Esat et al., 1999) and other corals from Tahiti from Hole M0019A-27R to 29R (Thomas et al., 2009) suggest this time was during a millennial scale lowstand which followed a brief period when sea level was higher, and preceded sea level rise towards the interglacial of MIS 5.5.

Both Fujita et al. (2010) and Iryu et al. (2010) identify an increase of water-depth in the cores immediately above M0005D-20R (cores 19R-16R, Fig. 1), in the case of Fujita et al. from 45-75 m water depth. Although we cannot be certain as to the absolute age of these cores, they have been shown to record the Blake geomagnetic excursion (115-120 ka) (Menabreaz et al., 2009). These water-depth interpretations are, therefore, consistent with the rise in sea level during the 
327 level was high during the MIS 5.5 highstand. Hypothesised ages, positions and hence paleo

328 water-depths of these cores are illustrated by open triangles in Fig. 3. Assuming a subsidence rate of $3290.25 \mathrm{mka}^{-1}$ the corals in M0005D-20R-2W were deposited at $84 \mathrm{mbsl}$. If the MIS 5.5 highstand was $330 \sim-8 \mathrm{mbsl}$ (Kopp et al 2009) then the maximum water-depth that could have existed above these 331 corals was $94 \mathrm{~m}$ (including $2 \mathrm{~m}$ of subsidence from $133 \mathrm{ka}$ to the time of the maximum highstand). 332 If core M0005D-16R is indeed MIS5.5 age then this would imply a water-depth of $83 \mathrm{~m}$ (16R is $33311 \mathrm{~m}$ above $20 \mathrm{R}$ in the hole), which is in remarkably good agreement with the paleo water-depth 334 estimation of Fujita et al of $75 \pm 15 \mathrm{~m}$. This age constraint therefore indicates that both methods 335 for paleo water-depth estimation are sensitive to increasing water-depth and have accurately recorded the sea level rise over the latter part of the penultimate deglaciation (Termination II).

Further comparisons between the age constraints and the paleo water-depth interpretations can be made in the older sections of Hole M0005D. Iryu et al. (2010) suggest M0005D-23R to 24R, characterized as a sandy bioclastic grainstone with massive Porites colonies, is representative of a shallow water environment at the beginning of the penultimate deglaciation which is then punctuated by a sea level reversal (Andrews et al., 2007; Esat et al., 1999; Siddall et al., 2006; Thomas et al., 2009) from deeper water in M0005D-22R to 21R (characterised by bioclastic packstones and microbiolites with encrusting corals) back to shallow water in M0005D-21R to 20R (coralgal framestone consisting of massive Porites). Fujita et al. (2010) also suggest M0005D-23R to 24R is shallow water deposit from the beginning of termination II, but has no data to constrain the water-depth from M0005D 22R-21R. Ages of M0005D-23R to 24R are much older (MIS 9) than is assumed by Fujita et al. (2010) and Iryu et al. (2010). Because there is no direct age control on the core sections $21 \mathrm{R}$ and $22 \mathrm{R}$ it is entirely possible that the age interpretation of Iryu et al. (2010) is 
correct, although it is just as feasible that the material from these core sections was deposited during

351 MIS 7 or 9.

352

353

The U-Th data combined with the minimum subsidence rate constraint has shown the M0005D-23R to 24R corals to be of MIS 9 age rather than from the early deglacial of the MIS 6-5 transition. The paleo depth of these corals has been estimated as $15 \pm 15 \mathrm{~m}$ on the basis of foraminiferal assemblage (Fujita et al., 2010) and also "shallow" ( $<20 \mathrm{~m}$ water-depth) on the basis of nongenticulate coralline algae (Iryu et al., 2010). A constraint on the maximum possible paleo water-depth available for these corals to grow, based on a minimum subsidence rate of $0.25 \mathrm{mka}^{-1}$ and sea level history is $45 \mathrm{~m}$ (Fig. 3). The constraints on subsidence rate $\left(0.25-0.39 \mathrm{mka}^{-1}\right)$ are however loose enough for this estimate to be as shallow as zero (this is from the construction of the maximum subsidence rate being constrained by the criterion that these corals must have grown below sea level).

A coral from core M0005D-30R has been found to display considerable open system behaviour for U-Th such that an accurate age cannot be determined. It is however interesting to note that using an open-system correction (Thompson et al., 2003), assuming an initial seawater $\left({ }^{234} \mathrm{U} /{ }^{238} \mathrm{U}\right.$ ) of 1.146, the untreated coral and one of the leached aliquots appear to be of MIS 11 age, although when considering the scatter of the other leached aliquots it is not clear that such an open-system correction is merited (other sub-samples of the same coral suggest an older MIS 13 age (Table 2)).

370 That section $30 \mathrm{R}$ is below $23 \mathrm{R}$ and $24 \mathrm{R}$ infers that it is indeed older than them but it could be that

371 it is from some time in MIS 9 earlier than then, rather than necessarily being as old as MIS 11. The 372 occurrence of erosional features in core sections between 24R and 30R (Fig. 1a and h, and Iryu et al.

373 2010), however, suggest that there had been a fall in sea level between these to "dated" corals 
374 (potentially during MIS 10). This stratigraphic control implies that the older interpretation of MIS

37511 for section 30R is more likely, although the possibility of millennial scale sea level variability 376 during the MIS 9 highstand being responsible for the erosional features cannot be discounted. The 377 only paleo water-depth estimates for sections 29R-36R are by Iryu et al. (2010), and are all 378 "shallow" except for 29R which displays a rhodolith assemblage characteristic of "deep" water (> $37950 \mathrm{~m}$ water-depth). If the minimum subsidence rate of $0.25 \mathrm{mka}^{-1}$ is considered, and it is assumed 380 that core 29R is of MIS 11 age (based on a tenuous open-system age interpretation, and position 381 below an unconformity assumed to represent MIS 10) then the maximum possible water-depth is 382 $\sim 40 \mathrm{~m}$ (Fig. 3). The shallow water depth inferred for 30R therefore may reflect lower sea level during the rise from MIS 12 to MIS 11. If, however, the corals from 29R are from MIS 9 then the maximum available water-depth is $\sim 58 \mathrm{~m}$. Faster rates of subsidence would reduce these available water-depths, therefore if the corals from $29 \mathrm{R}$ are representative of deep water then the upper estimate of subsidence rate becomes less likely.

The robustness of paleo water depth reconstructions can also be assessed from cores covering the last deglaciation, where radiocarbon chronology, the elevation of the samples and knowledge of sea level during the deglaciation can be used to provide "known paleo-bathymetry" to test reconstructions. Here we investigate reconstructions based on microbioerosion patterns. Since light controls the occurrence of phototrophic endoliths, their traces left in corals from different waterdepths (microbioerosion patterns) reflect different stages of illumination (photic zones), which can

394 be used to reconstruct paleo water-depths (e.g. Vogel and Marincovich, 2004). At Tahiti, the microbioerosion patterns in Holocene corals sampled in cores from around $115 \mathrm{mbsl}$ (M0024A-11R: 14800 cal. yr BP) to 55 mbsl (M0007B-11R: 9280 cal. yr BP) indicate increasing 
sea level (Heindel et al., 2009b). For example at around $115 \mathrm{mbsl}$ microbioerosion in the corals of

399 core M0024A-11R indicates shallow euphotic to deep euphotic conditions, whereas

400 microbioeroders in the immediately overlying red algal crusts and microbialites imply dysphotic

401 conditions, ie. an increace in water-depth. In combination with calibrated AMS 14C ages, which

402 indicate a significant time delay of $\sim 600$ years between coral growth and microbialite development

403 (Seard et al., 2011), the significantly changing microbioerosion patterns in the different substrates

404 next to each other reflect the rapid rise in sea level around Meltwater Pulse 1A (Bard et al., 1996;

405 Heindel et al., 2009b). This expected finding therefore adds confidence to paleo water-depth

406 reconstructions based on microbioerosional patterns. Although, as with all paleodepth

407 reconstruction, care must be taken to consider the potential of other environmental factors that may

408 influence the "water depth proxy". For example the potential of water turbidity to condense photic 409 zones and hence bias paleodepth estmates to deeper values (Heindel et al., 2009a, b).

\section{5. Conclusions}

Leaching of shallow water corals that display "open system" U-Th behaviour has the potential to remove $\mathrm{U}$ and Th added to the coral's surface leaving a residue that is closer to a closed system, however the resulting residue may not be considered to be representative of a closed system.

A minimum subsidence rate constrains the possible ages of sections $23 \mathrm{R}$ and $24 \mathrm{R}$ to highstands MIS $6.5,7,8.5,9$, or 11, and the U-Th data further limits the possible age of corals from these sections to be MIS 9 .

This extra age constraint places an absolute upper limit on the subsidence rate of 0.39 
422 water-depth for older corals suggest that this upper limit may be too high and a subsidence rate 423 more similar to the minimum of $0.25 \mathrm{mka}^{-1}$ may be more appropriate.

424 Comparison of constraints, provided by U-Th dating and subsidence rate, to estimates of 425 paleo water-depths based on sedimentary facies and foraminiferal/algal/microbioeroding 426 assemblages illustrate the accuracy of the paleo water-depth estimates in the absence of prior 427 knowledge of the age and hence expected water-depth.

428

\section{Acknowledgements} We would like to thank IODP Expedition 310 Scientists for their efforts during sample collection aboard the DP Hunter, and during core processing at the Bremen Core Repository - for which we would also like to thank the BCR staff for their assistance. We thank also, the organizers of the WHOI/IMAGES/PAGES/PALSEA workshop: "Understanding Future Sea Level Rise: the challenges of dating past interglacials" for informative discussion and constructive criticisms, and two reviewers for their thorough inspection of this manuscript and their constructive comments, which have greatly improved this manuscript. 
Andersen, M.B., Stirling, C.H., Potter, E.K., Halliday, A.N., Blake, S.G., McCulloch, M.T., Ayling, B.F. and O'Leary, M.J., 2010. The timing of sea-level high-stands during Marine Isotope Stages 7.5 and 9: Constraints from the uranium-series dating of fossil corals from Henderson Island. Geochimica et Cosmochimica Acta, 74(12): 3598-3620.

Andrews, J.E., Portman, C., Rowe, P.J., Leeder, M.R. and Kramers, J.D., 2007. Sub-orbital sea-level change in early MIS 5e: New evidence from the Gulf of Corinth, Greece. Earth and Planetary Science Letters, 259(3-4): 457-468.

Bard, E., Hamelin, B., Arnold, M., Montaggioni, L., Cabioch, G., Faure, G. and Rougerie, F., 1996. Deglacial sea-level record from Tahiti corals and the timing of global meltwater discharge. Nature, 382: 241-244.

Bintanja, R. and van de Wal, R.S.W., 2008. North American ice-sheet dynamics and the onset of 100,000-year glacial cycles. Nature, 454(7206): 869-872.

Bird, E.C.F., 1993. Submerging Coasts: The Effects of a Rising Sea Level on Coastal Environments. Wiley, Chichester, 184 pp.

Cabioch G., Montaggioni L.F., Faure G., Laurenti A. (1999) Reef coralgal assemblages as recorders of paleobathymetry and sea level changes in the Indo-Pacific province. Quaternary Science Reviews, 18: 1681-1695.

Camoin, G., Seard, C., Deschamps, P., Webster, J., Abbey, E., Braga, J.-C., Iryu, Y., Durand, N., Bard, E., Hamelin, B., Yokoyama, Y., Thomas, A.L., Henderson, G.M. and Dussouillez, P., In Review. Reef response to sea-level and environmental changes during the last deglaciation. IODP Expedition 310 "Tahiti Sea Level". Geology.

Camoin, G.F., Iryu, Y., McInroy, D.B. and Expedition 310 Scientists, 2007. Proceedings of the IODP, 310. Integrated Ocean Drilling Program Management International, Inc., Washington, DC.

Chappell, J. and Polach, H., 1991. Post-glacial sea-level rise from a coral record at Huon Peninsula, Papua New Guinea. Nature, 349: 147-149.

Cheng, H., Edwards, R.L., Hoff, J., Gallup, C.D., Richards, D.A. and Asmerom, Y., 2000. The half lives of uranium-234 and thorium-230. Chemical Geology, 169: 17-33.

Courtney, R.C. and White, R.S., 1986. Anomalous Heat-Flow and Geoid across the Cape-Verde Rise - Evidence for Dynamic Support from a Thermal Plume in the Mantle. Geophysical Journal of the Royal Astronomical Society, 87(3): 815-867.

Deschamps, P., Durand, N., Bard, E., Hamelin, B., Camoin, G., Thomas, A.L., Henderson, G.M., Okuno, J. and Yokoyama, Y., In Revision. A dramatic ice sheet collapse at the onset of the Bølling warming at 14.6 kyr. Nature.

Esat, T.M., McCulloch, M.T., Chappell, J., Pillans, B. and Omura, A., 1999. Rapid fluctuations in sea level recorded at Huon Peninsula during the penultimate deglaciation. Science, 283(5399): 197-201.

Esat, T.M. and Yokoyama, Y., 2006. Variability in the uranium isotopic composition of the oceans over glacial-interglacial timescales. Geochimica et Cosmochimica Acta, 70(16): 4140-4150.

Expedition 310 Scientists, 2007. Maraa western transect: Sites M0005-M0007. In: G.F. Camoin, Y. Iryu, D.B. McInroy and Expedition 310 Scientists (Editors), Proceedings of the IODP, 310 Integrated Ocean Drilling Program Management International, Inc., Washington, DC.

Fadil, A., Sichoix, L., Barriot, J.P., Ortega, P. and Willis, P., 2011. Evidence for a slow subsidence of the Tahiti Island from GPS, DORIS, and combined satellite altimetry and tide gauge sea level records. Comptes Rendus Geoscience, 343 (5): 331-341 
Fujita, K., Omori, A., Yokoyama, Y., Sakai, S. and Iryu, Y., 2010. Sea-level rise during Termination II inferred from large benthic foraminifers: IODP Expedition 310, Tahiti Sea Level. Marine Geology, 271, 1-2, 149-155

Gallup, C.D., Edwards, R.L. and Johnson, R.G., 1994. The Timing of High Sea Levels over the Past 200,000 Years. Science, 263(5148): 796-800.

Glaub, I., Gektidis, M. and Vogel, K., 2002. Microborings from different North Atlantic shelf areas - variability of the euphotic zone extension and implications for paleodepth reconstructions. Courier Forschungsinstitut Senckenberg, 237: 25-37.

Heindel, K., Westphal, H., Wisshak, M., 2009a. Bioerosion in the reef framework, IODP Expedition \#310 off Tahiti (Tiarei, Mara'a, and Faa'a); Proceedings of the IODP, 310, doi:10.2204/iodp.proc.310.201.2009, 28p.

Heindel, K., Wisshak, M. and Westphal, H. 2009b. Microbioerosion in Tahitian reefs: A record of environmental change during the last deglacial sea-level rise (IODP 310). Lethaia, 42: 322340.

Henderson, G.M., 2002. Seawater $\left({ }^{234} \mathrm{U} /{ }^{238} \mathrm{U}\right)$ during the last 800 thousand years. Earth and Planetary Science Letters, 199(1-2): 97-110.

Henderson, G.M., Slowey, N.C. and Fleisher, M.Q., 2001. U-Th dating of carbonate platform and slope sediments. Geochimica Cosmochimica Acta, 65(16): 2757-2770.

Hildenbrand, A., Gillot. P-Y., and Le Roy, I., 2004. Volcano-tectonic and geochemical evolution of an oceanic intra-plate volcano: Tahiti-Nui (French Polynesia). Earth and Planetary Science Letters, 217 (3-4) 349-265.

Hongo C., Kayanne H. 2010 Holocene sea-level record from corals: Reliability of paleodepth indicators at Ishigaki Island, Ryukyu Islands, Japan. Palaeogeography, Palaeoclimatology, Palaeoecology. $287:$ 143-151.

Hopley D (1986) Coral and reefs as indicators of paleo-sea levels, with special reference to the Great Barrier Reef. In: Van de Plassche O (ed): Sea-level research: a manual for the collection and evaluation of data, Geo Books, Norwich: 195-228.

Humblet, M., Iryu, Y. and Nakamori, T., 2009. Variations in Pleistocene coral assemblages in space and time in southern and northern Central Ryukyu Islands, Japan. Marine Geology, 259(14): $1-20$.

Inwood, J., Brewer, T., Braaksma, H. and Pezard, P., 2008. Integration of core, logging and drilling data in modern reefal carbonates to improve core location and recovery estimates (IODP Expedition 310). Journal of the Geological Society, 165: 585-596.

Iryu, Y., Takahashi, Y., Fujita, K., Camoin, G., Cabioch, G., Matsuda, H., Sato, T., Sugihara, K., Webster, J.M. and Westphal, H., 2010. Sealevel history recorded in the Pleistocene carbonate sequence in IODP Hole 310-M0005D, off Tahiti. Island Arc, 19(4): 690-706.

Kopp, R.E., Simons, F.J., Mitrovica, J.X., Maloof, A.C. and Oppenheimer, M., 2009. Probabilistic assessment of sea level during the last interglacial stage. Nature, 462(7275): 863-867.

LeRoy, I., 1994. Evolution des volcans en système de point chaud: île de Tahiti, archipel de la Société (Polynésie française), Paris XI, Orsay.

Lisiecki, L.E. and Raymo, M.E., 2005. A Pliocene-Pleistocene stack of 57 globally distributed benthic delta O-18 records. Paleoceanography, 20(1): PA1003.

Lomitschka, M. and Mangini, A., 1999. Precise Th/U-dating of small and heavily coated samples of deep sea corals. Earth and Planetary Science Letters, 170: 391-401.

Ludwig K.R. 2003. User's Manual for ISOPLOT/Ex 3.00. A Geochronological Toolkit for Microsoft Excel.Berkeley Geochronology Center Special Publication. No. 4.70 pp.

Martinson, D.G., Pisias, N.G., Hays, J.D., Imbrie, J., Moore, T.C. and Shackleton, N.J., 1987. Age dating and the orbital theory of the ice ages: development of a high resolution 0 to 300,000-year 
chronostratigraphy. Quaternary Research, 27: 1-29.

Mason, A.J. and Henderson, G.M., 2010. Correction of multi-collector-ICP-MS instrumental biases in highprecision uranium-thorium chronology. International Journal of Mass Spectrometry, 295(1-2): 2635.

Menabreaz, A., Thouveny, N., Camoin, G., and Lund, S. P., 2010. Paleomagnetic record of the late Pleistocene reef sequence of Tahiti (French Polynesia): A contribution to the chronology of the deposits. Earth and Planetary Science Letters 294, 58-68.

Montaggioni, L.F., 1988. Holocene reef growth history in mid-plate high volcanic islands. Proceedings of the Fifth International Coral Reef Congress., 3, 455-460.

Montaggioni, L.F., 2005. History of Indo-Pacific coral reef systems since the last glaciation; development patterns and controlling factors. Earth-Science Reviews, 71(1-2): 1-75.

Moore, J.G., 1970. Relationship between subsidence and volcanic load, Hawaii. Bulletin of Volcanology, 34(2): 562-576.

Muhs, D.R., Simmons, K.R. and Steinke, B., 2002. Timing and warmth of the Last Interglacial period: new U-series evidence from Hawaii and Bermuda and a new fossil compilation for North America. Quaternary Science Reviews, 21: 1355-1383.

Muller, R.D., Sdrolias, M., Gaina, C. and Roest, W.R., 2008. Age, spreading rates, and spreading asymmetry of the world's ocean crust. Geochemistry Geophysics Geosystems, 9: -.

Parrenin, F., Barnola, J.M., Beer, J., Blunier, T., Castellano, E., Chappellaz, J., Dreyfus, G., Fischer, H., Fujita, S., Jouzel, J., Kawamura, K., Lemieux-Dudon, B., Loulergue, L., Masson-Delmotte, V., Narcisi, B., Petit, J.R., Raisbeck, G., Raynaud, D., Ruth, U., Schwander, J., Severi, M., Spahni, R., Steffensen, J.P., Svensson, A., Udisti, R., Waelbroeck, C. and Wolff, E., 2007. The EDC3 chronology for the EPICA dome C ice core. Climate of the Past, 3(3): 485-497.

Peltier, W.R. and Fairbanks, R.G., 2006. Global glacial ice volume and Last Glacial Maximum duration from an extended Barbados sea level record. Quaternary Science Reviews, 25(2324): 3322-3337.

Perry, C.T. and Macdonald, I.A., 2002. Impacts of light penetration on the bathymetry of reef microboring communities: implications for the development of microendolithic trace assemblages. Palaeogeography, Palaeoclimatology, Palaeoecology, 186: 101-113.

Pirazzoli, P.A., Montaggioni, L.F., Delibrias, G., Faure, G. and Salvat, B., 1985. Late Holocene sea-level changes in the Society Islands and in the northwest Tuamotu Atolls. In: C. Gabrie, J.L. Toffart and B. Salvat (Editors), Proceedings of the Fifth International Coral Reef Congress. Symposia and Seminars (A), Tahiti.

Robinson, L.F., Belshaw, N.S. and Henderson, G.M., 2004a. U and Th concentrations and isotope ratios in modern carbonates and waters from the Bahamas. Geochimica et Cosmochimica Acta 68, (8): 1777-1789.

Robinson, L.F., Henderson, G.M., Hall, L. and Matthews, I., 2004b. Climatic control of riverine and seawater uranium-isotope ratios. Science, 305: 851-854.

Rohling, E.J. et al., 2009. Antarctic temperature and global sea level closely coupled over the past five glacial cycles. Nature Geoscience, 2: 500-504.

Scholz, D., Mangini, A. and Felis, T., 2004. U-series dating of diagenetically altered fossil reef corals Earth and Planetary Science Letters, 218: 163-178.

Seard, C., Camoin, G., Yokoyama, Y., Matsuzaki, H., Durand, N., Bard, E., Sepulcre, S., and Deschamps, P., 2011. Microbialite development patterns in the last deglacial reefs from Tahiti (French Polynesia; IODP Expedition \#310): implications on reef framework architecture. Marine Geology, 279, 63-86.

Siddall, M., Bard, E., Rohling, E.J. and Hemleben, C., 2006. Sea-level reversal during Termination II. Geology, 34(10): 817-820. 
605

606
Stein, C.A. and Stein, S., 1992. A Model for the Global Variation in Oceanic Depth and Heat-Flow with Lithospheric Age. Nature, 359(6391): 123-129.

Szabo, B.J., Ludwig, K.R., Muhs, D.R. and Simmons, K.R., 1994. Th-230 Ages of Corals and Duration of the Last Interglacial Sea-Level High Stand on Oahu, Hawaii. Science, 266(5182): 93-96.

Thomas, A.L., Henderson, G.M., Deschamps, P., Yokoyama, Y., Mason, A.J., Bard, E., Hamelin, B., Durand, N. and Camoin, G., 2009. Penultimate Deglacial Sea-Level Timing from Uranium/Thorium Dating of Tahitian Corals. Science, 324(5931): 1186-1189.

Thomas, A.L., Henderson, G.M. and Robinson, L.F., 2006. Interpretation of the 231Pa/230Th paleocirculation proxy: New water-column measurements from the southwest Indian Ocean. Earth and Planetary Science Letters, 241 493- 504.

Thompson, W.G., Spiegelman, M.W., Goldstein, S.L. and Speed, R.C., 2003. An open-system model for U-series age determinations of fossil corals. Earth and Planetary Science Letters, 210(1-2): 365-381.

Villemant, B. and Feuillet, N., 2003. Dating open systems by the 238U-234U-230Th method: application to quaternary reef terraces. Earth and Planetary Science Letters, 210: 105-118.

Vogel, K. and Marincovich Jr., L., 2004. Paleobathymetric implications of microborings in Tertiary strata of Alaska, USA. Palaeogeography, Palaeoclimatology, Palaeoecology, 206: 1-20.

Watts, A.B. and Zhong, S., 2000. Observations of flexure and the rheology of oceanic lithosphere. Geophysical Journal International, 142(3): 855-875.

Westphal, H., Heindel, K., Brandano, M., Peckmann, J. (2010) Genesis of microbialites as contemporaneous framework components of coral reefs, deglacial of Tahiti (IODP 310); Facies, 56, 337-352.

Zhong, S.J. and Watts, A.B., 2002. Constraints on the dynamics of mantle plumes from uplift of the Hawaiian Islands. Earth and Planetary Science Letters, 203(1): 105-116. 
606

607

608

609

610

611

612

613

614

615

616

617

618

619

620

621

622

623

624

625

626

627

628

629

630

631

632

633

634

635

636

Table Captions

\section{Table 1}

Uranium and thorium concentrations (expressed in mass per mass) and isotope ratios (expressed as activity ratios, using half lives according to Cheng et al. 2000). Italics denote data that have been previously published (Thomas et al., 2009). Uncertainties are based on the reproducibility of standard U and Th solutions, within a measurement session. Superscripts in sub-sample IDs denote where sub-samples have bee taken from the same coral specimen.

\section{Table 2}

Sample context and calculated ages. Depth below present sea level in meters (mbsl) that the coral was cored from. $\%$ of sample remaining following partial dissolution $(100 \%$, represents total dissolution of sample, with no leaching proceedure). Closed system age (before 1950 AD) and $\left({ }^{234} \mathrm{U} /{ }^{238} \mathrm{U}\right)$ at time of coral growth $\left(\left({ }^{234} \mathrm{U} /{ }^{234} \mathrm{U}\right)_{\mathrm{i}}\right)$, calculated using isoplot software (Ludwig, 2003) and the half lives of (Cheng et al., 2000). Open system ages are calculated using the approach of (Thompson et al., 2003) and assuming $\left({ }^{234} \mathrm{U} /{ }^{234} \mathrm{U}\right)_{\mathrm{i}}$ of modern seawater at 1.146 (Robinson et al., 2004a). Italics denote data that have been previously published (Thomas et al., 2009).

\section{Figure Captions}

\section{Figure 1}

Graphic log of the Pre-LGM sections of Hole IODP 310 M0005D (a), sedimentology (b and e), foraminifera (c) and nongeniculate coralline algal (f) assemblages with associated paleo water-depth interpretations ( $\mathrm{d}$ and $\mathrm{g}$ respectively). Panels a-g are adapted from Fujita et al. (2010) and Iryu et al. (2010). Core sections on which the U-Th data provide age control (h) are illustrated in black (closed-system U-Th age) and grey (marine isotope stage inferred from combination of open-system U-Th data and minimum subsidence rate), erosional contacts from (a) are re-illustrated in (h). Sea level records based on continuous $\delta^{18} \mathrm{O}$ (i): solid line, (Bintanja and van de Wal, 2008) on the LR04 timescale (Lisiecki and Raymo, 2005); dotted line (Rohling et al., 2009) on the EDC3 timescale (Parrenin et al., 2007). 


\section{$638 \quad$ Figure 2}

$639\left({ }^{234} \mathrm{U} /{ }^{238} \mathrm{U}\right)$ relationship with $\left({ }^{230} \mathrm{Th} /{ }^{238} \mathrm{U}\right)$ over time for a hypothetical closed system coral that had $640\left({ }^{234} \mathrm{U} /{ }^{238} \mathrm{U}\right)_{\mathrm{i}}$ of $1.146 \pm 0.005$ (grey band). Time is marked along the closed system band by marine 641 isotope stages following the numbering system of (Martinson et al., 1987). The darker grey sections 642 of the closed system band are the times when core section 23R was submerged (Fig. 3). Ellipses are 643 the $2 \sigma$ uncertainties of the U-Th data of this study. The black arrow represents the direction 644 coupled addition of ${ }^{234} \mathrm{U}$ and ${ }^{230} \mathrm{Th}$ would drive MIS 11 corals in a possible mode of open system 645 alteration (Thompson et al., 2003).

\section{Figure 3}

648 Plot of core section reconstructed depth vs. age for (A) $0.25 \mathrm{mka}^{-1}$ and (B) $0.35 \mathrm{mka}^{-1}$. Core sections 649 are shown in grey and sections which have age control provided by U-Th are highlighted in black. 650 Sea level history is shown as a black solid line (Bintanja and van de Wal, 2008) and black dotted line 651 (Rohling et al., 2009). For the $0.25 \mathrm{mka}^{-1}$ scenario the times when sea level was above the position 652 of core section 23R (and hence the only times during which corals could grow) are illustrated by 653 vertical grey bars. Open triangles highlight hypothesised ages and hence paleo water-depths of core 654 sections M0005D-19R to 16R, that record increasing paleo water-depth during the penultimate 655 deglaciation.

\section{Figure 4}

657 The MIS 9 portion of the closed system band from Fig. 2 with age isochrons (grey lines) marked 658 every $10 \mathrm{ka}$ (the isochrons represent where closed system samples would plot if they had exactly the 659 same age but had different $\left({ }^{234} \mathrm{U} /{ }^{238} \mathrm{U}\right)_{\mathrm{i}}$ - an impossible scenario for corals which should all have the 660 same $\left({ }^{234} \mathrm{U} /{ }^{238} \mathrm{U}\right)_{\mathrm{i}}$ because seawater should have homogenous uranium isotopes). The $\left({ }^{234} \mathrm{U} /{ }^{238} \mathrm{U}\right)$ and

$661\left({ }^{230} \mathrm{Th} /{ }^{238} \mathrm{U}\right)$ are plotted for the sub-samples of corals $23 \mathrm{R}-2 \mathrm{~W}-0,37 \mathrm{~cm}$ and $30 \mathrm{R}-1 \mathrm{~W}-119,135 \mathrm{~cm}$ 662 which had been subject to partial dissolution (ellipse size is analytical uncertainty). The darkness of 663 the ellipses indication the amount of the initial sub-sample remained following leaching, lighter 664 shades indicating greater dissolution. 
666 Table 1

\begin{tabular}{|c|c|c|c|c|c|c|c|c|c|c|c|}
\hline Sub-sample ID & $\begin{array}{l}\text { IODP Sample ID } \\
\text { 310-M0005D- }\end{array}$ & $\begin{array}{l}{ }^{238} \mathrm{U} \\
\mathrm{ppm}\end{array}$ & $2 \mathrm{~s}$ & $\begin{array}{l}{ }^{232} \mathrm{Th} \\
\mathrm{ppb}\end{array}$ & $2 \mathrm{~s}$ & $\begin{array}{c}\left({ }^{230} \mathrm{Th} /\right. \\
\left.{ }^{238} \mathrm{U}\right)\end{array}$ & $2 s$ & $\begin{array}{c}\left({ }^{234} \mathrm{U} /\right. \\
\left.{ }^{238} \mathrm{U}\right) \\
\end{array}$ & $2 \mathrm{~s}$ & $\begin{array}{l}\left({ }^{232} \mathrm{Th} /\right. \\
238 \mathrm{U}) \\
\end{array}$ & $2 \mathrm{~s}$ \\
\hline $5 D 8146 a 2^{a}$ & 20R-2W-0, 21 & 3.126 & 0.004 & 0.194 & 0.003 & 0.7866 & 0.0028 & 1.1024 & 0.0008 & 0.0000204 & 0.0000004 \\
\hline $5 D 8146 b^{a}$ & 20R-2W-0, 21 & 2.9457 & 0.0004 & 0.2445 & 0.0004 & 0.8020 & 0.0009 & 1.1007 & 0.0008 & 0.00002717 & 0.00000004 \\
\hline $5 D 8006 a 2^{b}$ & 20R-2W-14, 21 & 2.736 & 0.004 & 0.216 & 0.004 & 0.7949 & 0.0029 & 1.1081 & 0.0008 & 0.0000259 & 0.0000005 \\
\hline $5 D 8006 c^{b}$ & $20 \mathrm{R}-2 W-14,21$ & 2.5690 & 0.0008 & 0.08490 & 0.00014 & 0.7902 & 0.0009 & 1.1016 & 0.0008 & 0.000010821 & 0.000000018 \\
\hline $5 \mathrm{D} 7198 \mathrm{a}^{\mathrm{c}}$ & 24R-1W-73, 87 & 2.2911 & 0.0004 & 0.04475 & 0.00016 & 1.0810 & 0.0022 & 1.0686 & 0.0005 & 0.000006395 & 0.000000024 \\
\hline $5 \mathrm{D} 7198 \mathrm{~b}^{\mathrm{c}}$ & 24R-1W-73, 87 & 2.2922 & 0.0003 & 0.04366 & 0.00016 & 1.0787 & 0.0022 & 1.0684 & 0.0005 & 0.000006236 & 0.000000023 \\
\hline $5 \mathrm{D} 7198 \mathrm{c}^{\mathrm{c}}$ & 24R-1W-73, 87 & 3.0441 & 0.0004 & 1.4241 & 0.0023 & 1.0960 & 0.0012 & 1.0600 & 0.0008 & 0.0001532 & 0.0000003 \\
\hline 5D8256b1 & 24R-1W-51, 85 & 2.618 & 0.003 & 0.477 & 0.008 & 1.040 & 0.004 & 1.0671 & 0.0008 & 0.0000597 & 0.0000011 \\
\hline 5D23RTop_ac & 23R-2W-0, 37 & 2.3190 & 0.0003 & 0.0771 & 0.0004 & 1.0383 & 0.0019 & 1.0646 & 0.0007 & 0.00001088 & 0.00000005 \\
\hline 5D23RTop_apd & $23 \mathrm{R}-2 \mathrm{~W}-0,37$ & 1.9876 & 0.0003 & 3.745 & 0.018 & 1.0364 & 0.0019 & 1.0623 & 0.0007 & 0.000617 & 0.000003 \\
\hline 5D23RTop_bc & $23 \mathrm{R}-2 \mathrm{~W}-0,37$ & 2.5846 & 0.0020 & 0.1563 & 0.0007 & 1.0323 & 0.0021 & 1.0593 & 0.0007 & 0.00001980 & 0.00000010 \\
\hline 5D23RTop_bp ${ }^{d}$ & $23 \mathrm{R}-2 \mathrm{~W}-0,37$ & 2.5651 & 0.0009 & 3.290 & 0.016 & 1.0259 & 0.0019 & 1.0623 & 0.0007 & 0.0004199 & 0.0000020 \\
\hline 5D23RTop_cc & 23R-2W-0, 37 & 2.3938 & 0.0009 & 0.161 & 0.001 & 1.0291 & 0.0019 & 1.0638 & 0.0007 & 0.00002209 & 0.00000011 \\
\hline 5D23RTop_cpd & $23 \mathrm{R}-2 \mathrm{~W}-0,37$ & 2.6566 & 0.0013 & 1.341 & 0.006 & 1.0259 & 0.0020 & 1.0613 & 0.0007 & 0.0001653 & 0.0000008 \\
\hline 5D23RTop_dp & 23R-2W-0, 37 & 2.4011 & 0.0012 & 6.44 & 0.03 & 1.0234 & 0.0020 & 1.0643 & 0.0007 & 0.0008782 & 0.0000042 \\
\hline TFC 2 & 24R-1W-27, 33 & 2.2509 & 0.0010 & 0.0688 & 0.0003 & 1.0516 & 0.0020 & 1.0670 & 0.0007 & 0.00001000 & 0.00000005 \\
\hline TFC $3^{e}$ & 30R-1W-119, 135 & 2.2092 & 0.0012 & 0.1592 & 0.0008 & 1.0748 & 0.0021 & 1.0611 & 0.0007 & 0.00002360 & 0.00000011 \\
\hline $5 \mathrm{D} 8668 \mathrm{~b}^{\mathrm{e}}$ & 30R-1W-119, 135 & 2.3352 & 0.0003 & 0.1449 & 0.0003 & 1.0905 & 0.0013 & 1.0568 & 0.0009 & 0.00002031 & 0.00000004 \\
\hline $5 \mathrm{D} 8668 \mathrm{c}^{\mathrm{e}}$ & 30R-1W-119, 135 & 2.2480 & 0.0003 & 0.1383 & 0.0005 & 1.0958 & 0.0014 & 1.0595 & 0.0009 & 0.00002014 & 0.00000007 \\
\hline 5D8668dpe & 30R-1W-119, 135 & 2.3745 & 0.0003 & 0.2373 & 0.0006 & 1.0541 & 0.0014 & 1.0541 & 0.0009 & 0.00003273 & 0.00000008 \\
\hline
\end{tabular}


668 Table 2

\begin{tabular}{|c|c|c|c|c|c|c|c|c|c|c|}
\hline Sub-sample ID & mbsl & $\begin{array}{c}\% \\
\text { Residue }\end{array}$ & $\begin{array}{c}\text { Closed } \\
\text { System Age } \\
\text { ka BP }\end{array}$ & $2 \mathrm{~s}$ & $(234 \mathrm{U} / 238 \mathrm{U}) \mathrm{i}$ & $2 \mathrm{~s}$ & $\begin{array}{c}\text { Open } \\
\text { System Age } \\
\text { ka BP }\end{array}$ & $2 \mathrm{~s}$ & $\begin{array}{c}\% \\
\text { calcite } \\
\end{array}$ & $2 \mathrm{~s}$ \\
\hline $5 D 8146 a 2^{a}$ & 117.52 & $100 \%$ & 132.4 & 0.9 & 1.1489 & 0.0012 & 130.7 & 1.0 & $1.9 \%$ & $0.3 \%$ \\
\hline $5 D 8146 b^{a}$ & 117.52 & $100 \%$ & 137.9 & 0.4 & 1.1487 & 0.0011 & 136.3 & 0.8 & & \\
\hline $5 D 8006 a 2^{b}$ & 117.66 & $100 \%$ & 133.6 & 1.0 & 1.1576 & 0.0012 & 128.3 & 1.1 & $0.3 \%$ & $0.2 \%$ \\
\hline $5 D 8006 c^{b}$ & 117.66 & $100 \%$ & 133.7 & 0.4 & 1.1483 & 0.0011 & 132.4 & 0.7 & & \\
\hline $5 \mathrm{D} 7198 \mathrm{a}^{\mathrm{c}}$ & 128.24 & $100 \%$ & 472 & 15 & 1.261 & 0.011 & 379 & 8 & & \\
\hline $5 \mathrm{D} 7198 \mathrm{~b}^{\mathrm{c}}$ & 128.24 & $100 \%$ & 460 & 14 & 1.251 & 0.009 & 376 & 8 & & \\
\hline $5 \mathrm{D} 7198 \mathrm{c}^{\mathrm{c}}$ & 128.24 & $100 \%$ & & & & & 502 & 18 & & \\
\hline 5D8256b1 & 128.02 & $100 \%$ & 338 & 8 & 1.174 & 0.004 & 318 & 6 & $0.2 \%$ & $0.2 \%$ \\
\hline 5D23RTop_ac & 125.95 & $84 \%$ & 340 & 4 & 1.1691 & 0.0021 & 324 & 4 & & \\
\hline 5D23RTop_apd & 125.95 & $89 \%$ & 343 & 5 & 1.1640 & 0.0021 & 329 & 4 & & \\
\hline 5D23RTop_bcd & 125.95 & $71 \%$ & 342 & 5 & 1.1558 & 0.0022 & 334 & 4 & & \\
\hline 5D23RTop_bpd & 125.95 & $56 \%$ & 322 & 4 & 1.1547 & 0.0018 & 315 & 3 & & \\
\hline 5D23RTop_cc & 125.95 & $100 \%$ & 324 & 4 & 1.1595 & 0.0019 & 315 & 3 & & \\
\hline 5D23RTop_cp ${ }^{d}$ & 125.95 & $65 \%$ & 324 & 4 & 1.1532 & 0.0019 & 318 & 3 & & \\
\hline 5D23RTop_dpd & 125.95 & $100 \%$ & 313 & 4 & 1.1558 & 0.0018 & 306 & 3 & & \\
\hline TFC 2 & 127.78 & $100 \%$ & 364 & 6 & 1.1876 & 0.0028 & 334 & 5 & & \\
\hline TFC 3 e & 141.98 & $100 \%$ & 503 & 20 & 1.25 & 0.01 & 409 & 9 & & \\
\hline $5 \mathrm{D} 8668 \mathrm{~b}^{\mathrm{e}}$ & 141.98 & $84 \%$ & & & & & 513 & 21 & $0.42 \%$ & $0.04 \%$ \\
\hline $5 \mathrm{D} 8668 \mathrm{c}^{\mathrm{e}}$ & 141.98 & $82 \%$ & & & & & 507 & 21 & & \\
\hline 5D8668dpe & 141.98 & $75 \%$ & 432 & 9 & 1.183 & 0.003 & 399 & 7 & & \\
\hline
\end{tabular}


$670 \quad$ Figure 1

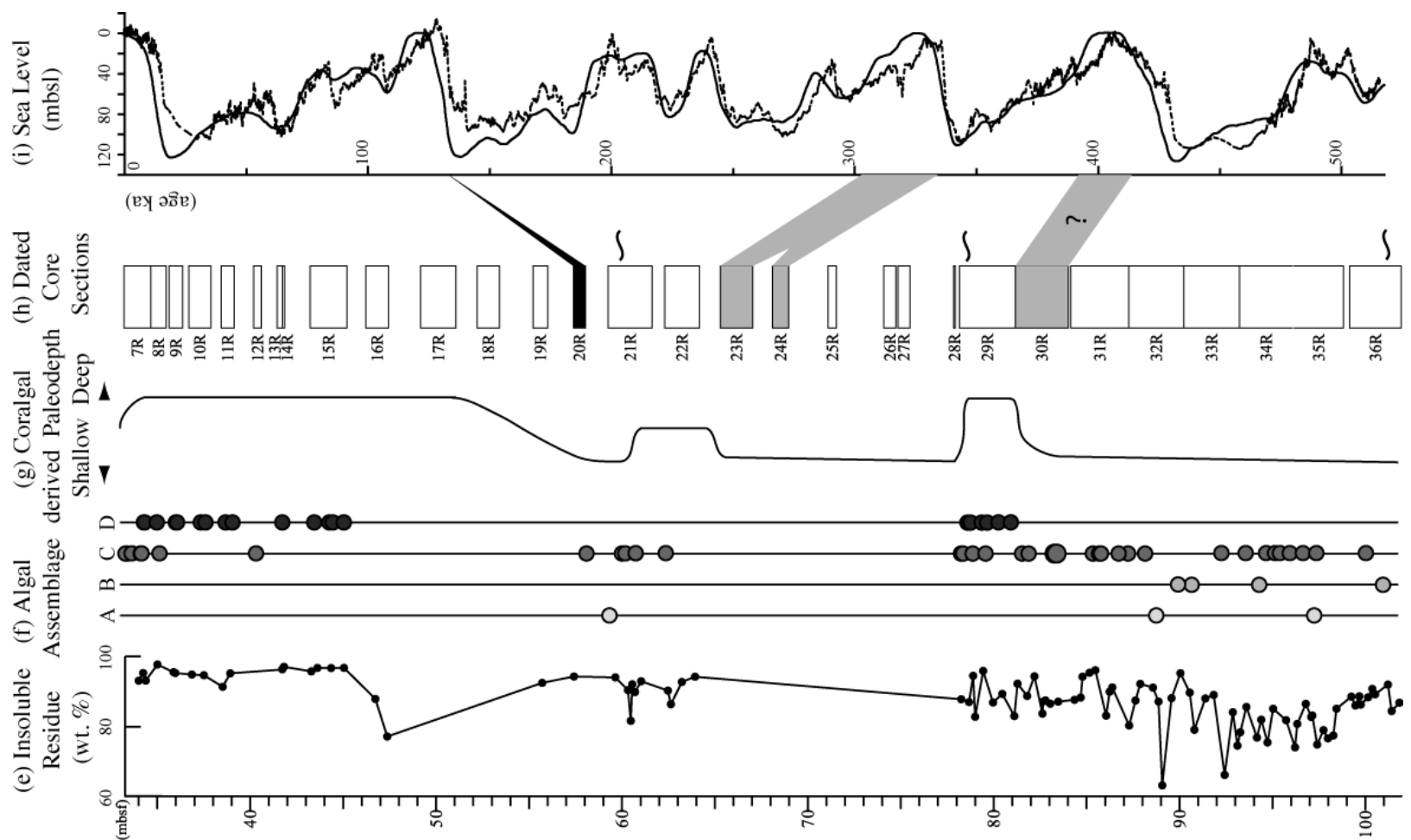

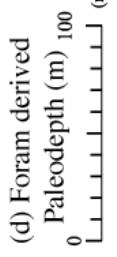
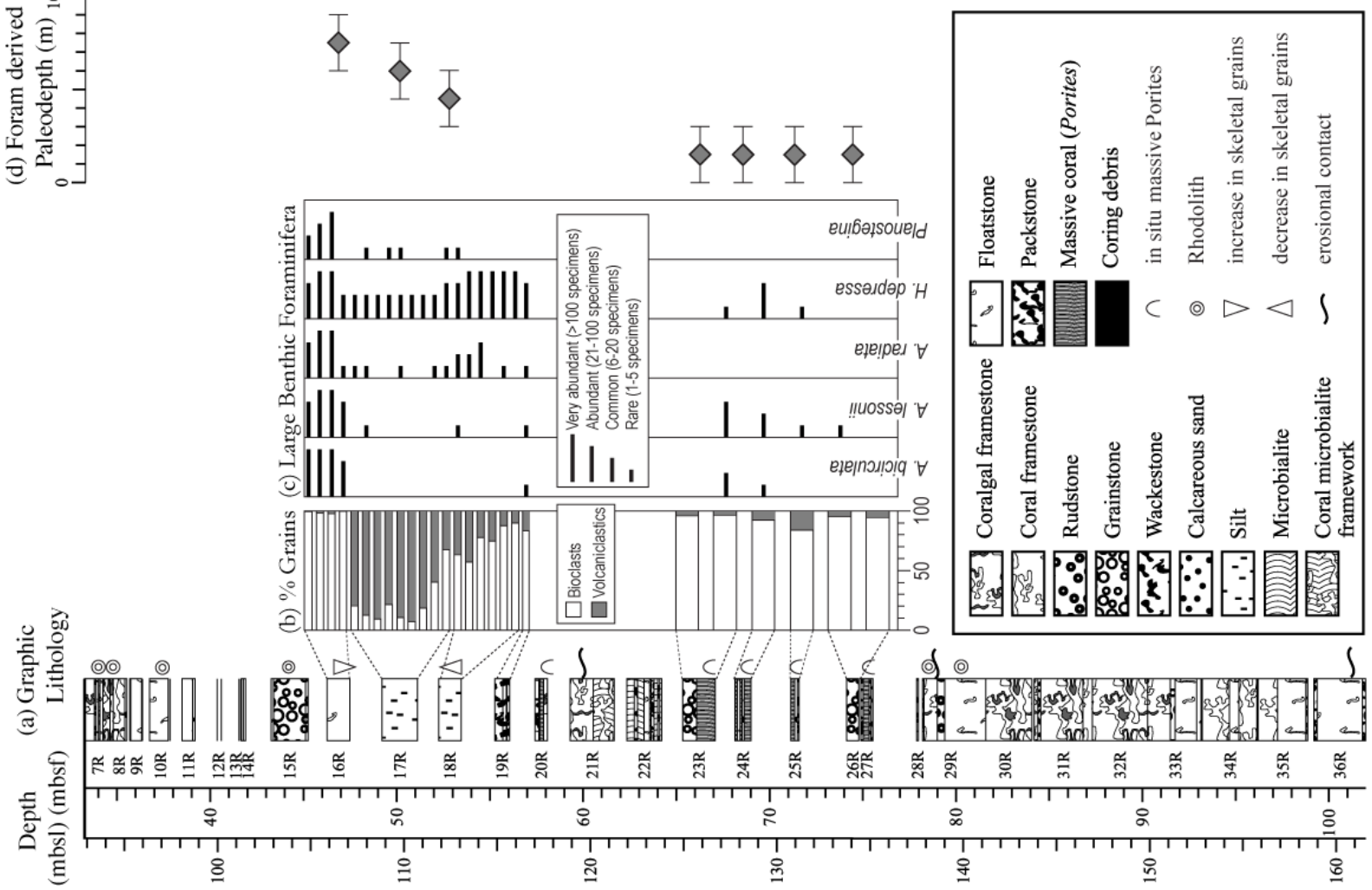
672 Figure 2

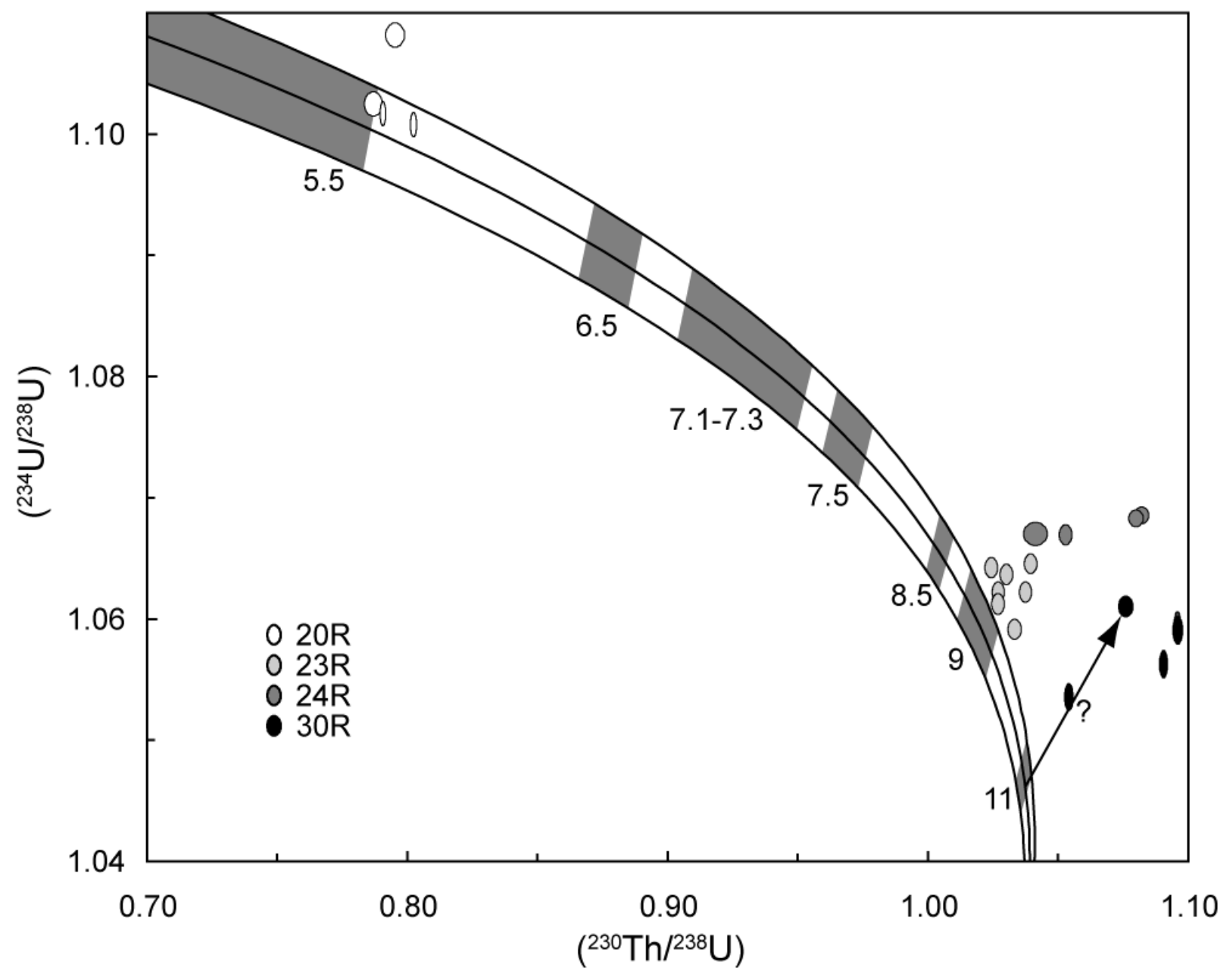


$674 \quad$ Figure 3

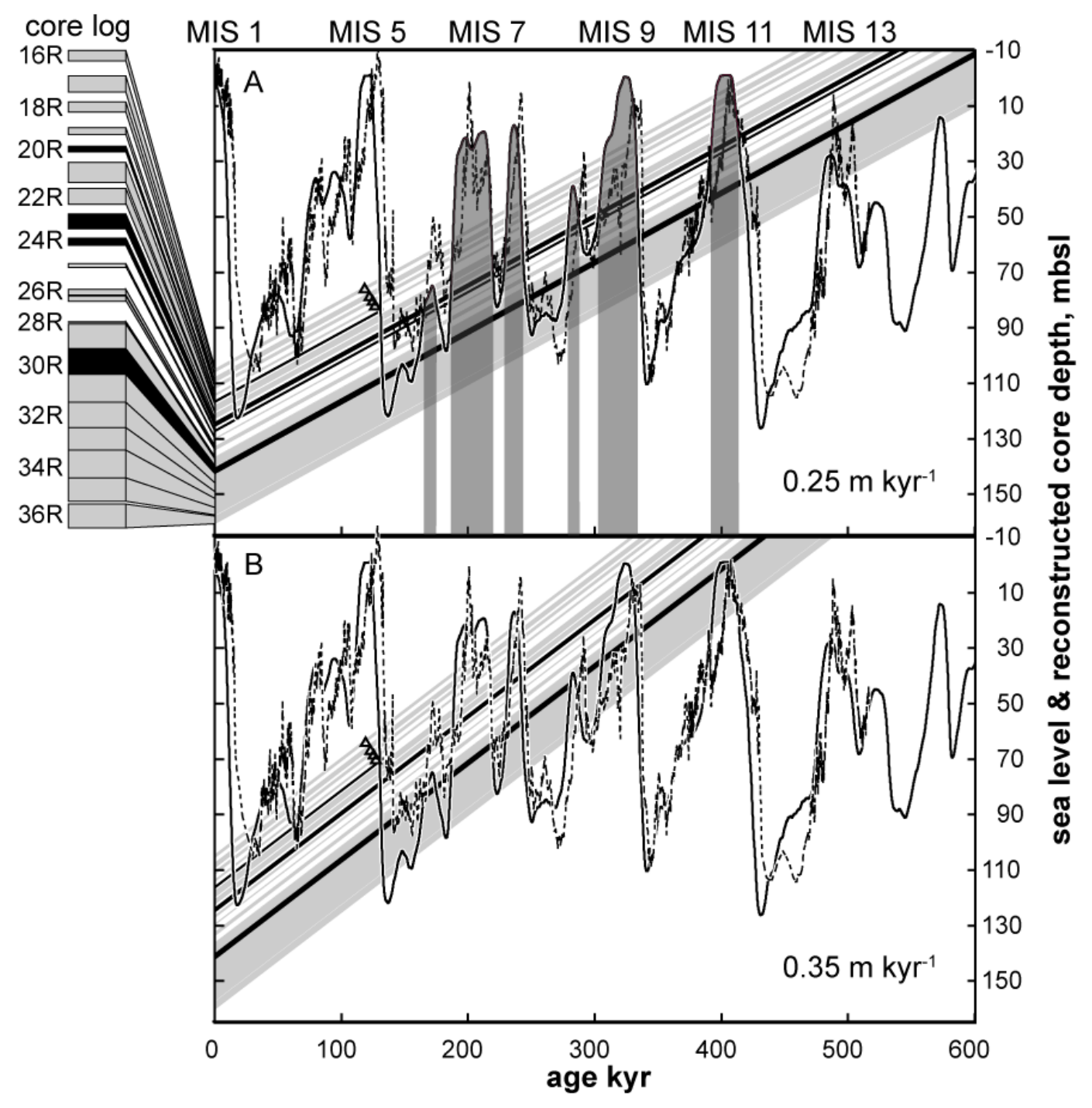


$676 \quad$ Figure 4

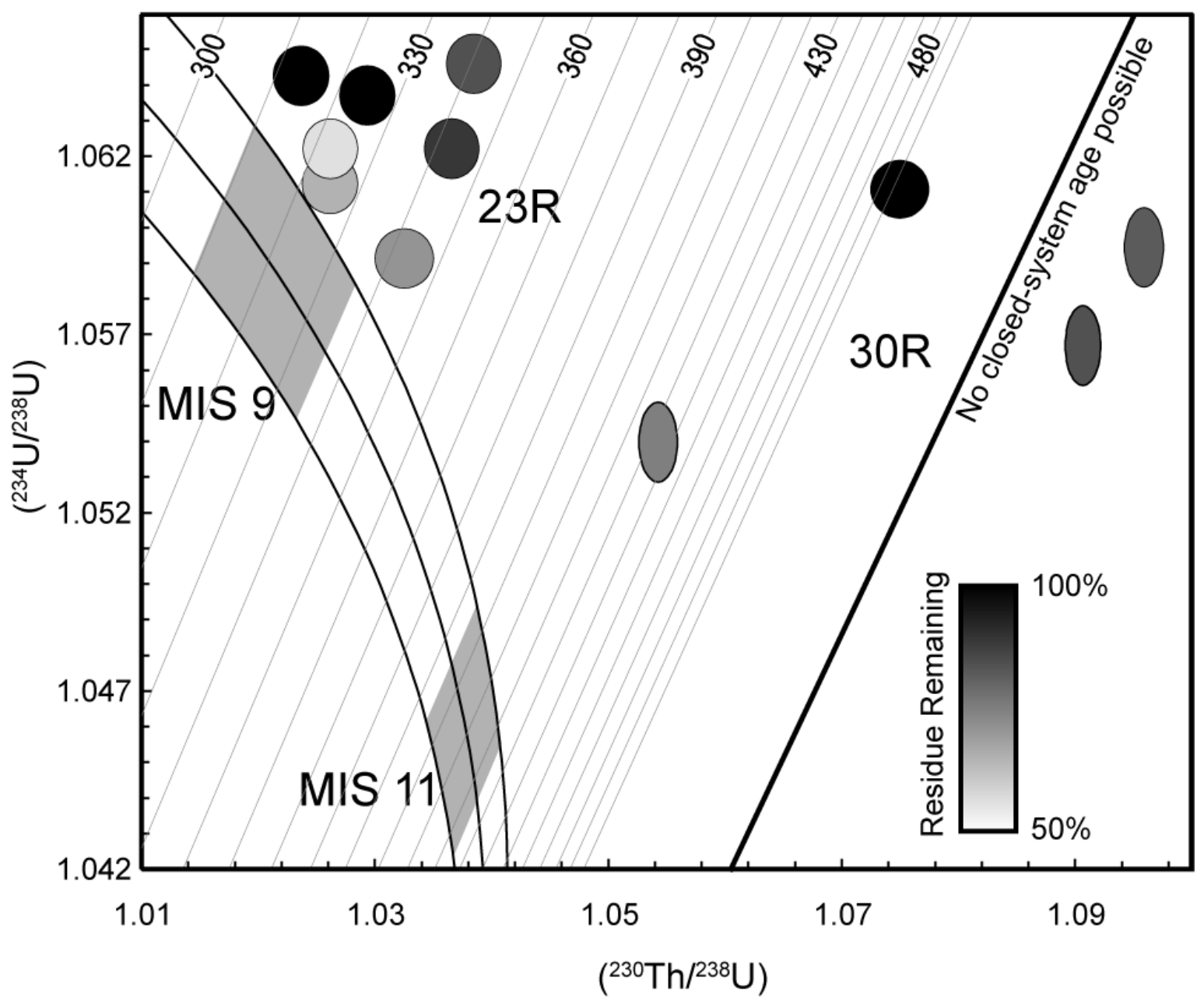

